\title{
Faktor-Faktor Yang Mempengaruhi Tingkat Kepatuhan Wajib Pajak Orang Pribadi di Kantor Pelayanan Pajak Pratama Semarang Selatan Tahun 2019
}

\author{
Arbani Rusdi ${ }^{1}$, Prabowo Yudo Jayanto \\ ${ }^{1}$ Program Studi Akuntansi \\ Universitas Negeri Semarang \\ Kampus Sekaran, Gunungpati, Semarang, Indonesia \\ e-mail: gunturgunt@gmail.com \\ ${ }^{2}$ Universitas Negeri Semarang \\ Kampus Sekaran, Gunungpati, Semarang, Indonesia \\ e-mail: gunturgunt@gmail.com

\begin{tabular}{ccc}
\hline Diterima & Direvisi & Disetujui \\
$02-02-2020$ & $11-02-2020$ & $14-02-2020$ \\
\hline
\end{tabular}

\begin{abstract}
Abstrak - Riset ini memiliki tujuan untuk menguji pengaruh e-registration, e-filing, e-billing, kualitas pelayanan, pemahaman peraturan pajak, dan sanksi pajak terhadap tingkat kepatuhan Wajib Pajak. Populasi yang digunakan dalam riset ini yaitu Wajib Pajak Orang Pribadi yang terdaftar di Kantor Pelayanan Pajak (KPP) Pratama Semarang Selatan yang berjumlah 16.356 Wajib Pajak Orang Pribadi. Sampel dalam riset ini adalah 50 responden yang diperoleh menggunakan metode insidental sampling. Data dianalisis dengan menggunakan Structural Equation Modeling (SEM) dengan berbasis Partial Least Square (PLS) Path Modeling menggunakan software SmartPLS 3.0. Hasil riset ini menunjukkan bahwa e-registration, e-filing, dan kualitas pelayanan secara parsial memiliki pengaruh terhadap tingkat kepatuhan Wajib Pajak, sedangkan $e$-billing, pemahaman peraturan pajak, dan sanksi pajak tidak memiliki pengaruh terhadap tingkat kepatuhan Wajib Pajak. Kesimpulan dalam riset ini yaitu variabel -registration, e-filing, dan kualitas pelayanan memiliki hubungan positif dan signifikan terhadap kepatuhan Wajib Pajak, sedangkan variabel e-billing, pemahaman peraturan pajak, dan sanksi pajak tidak memiliki pengaruh terhadap tingkat kepatuhan Wajib Pajak.
\end{abstract}

Kata kunci: Kepatuhan Wajib Pajak, E-system, Pemahaman Peraturan Pajak

Abstract - This study aims to examine the effect of e-registration, e-filing, e-billing, service quality, understanding of taxation regulations, and tax penalties on the level of taxpayer compliance. The population in this study is 16.356 people in the area of Tax Service Office of Pratama in the city of Semarang Selatan. The sample in this study were 50 respondents obtained by the accidental sampling method. The Data were analyzed by using Structural Equation Modeling (SEM) with Partial Least Square (PLS) Path Modeling using SmartPLS 3.0 software. The results showed that e-registration, e-filing, and service quality partially affected the taxpayer compliance while e-billing, understanding of taxation regulations, and tax penalties did not affect the taxpayer compliance. The conclusion of this research is e-registration, e-filing, and service quality have a positive and significantly influence to taxpayer compliance, while e-billing, understanding of taxation regulations, and tax penalties have no influence on the level of taxpayer compliance.

Keywords: Taxpayer Compliance, E-system, Understanding of Taxation Regulations

\section{PENDAHULUAN}

Indonesia adalah negara berkembang yang memiliki bermacam-macam sumber daya untuk menjadi negara makmur. Pendapatan negara Indonesia dibagi menjadi 2 sumber yaitu sumber pendapatan dalam negeri dan dari mancanegara. Sumber pendapatan dalam negeri yang paling besar kontribusinya adalah pajak. Pajak adalah salah satu sumber pendapatan negara terbesar dan berperan penting dalam pembangunan negara. Oleh karena itu tax harus dikelola dengan baik dan strategis.
Efektifitas dan efisiensi dalam pengelolaan pajak diwujudkan melalui reformasi perpajakan. Reformasi pajak dilaksanakan pemerintah untuk meningkatkan tax ratio. Rasio pajak atau tax ratio yaitu perbandingan antara pendapatan pajak terhadap Produk Domestik Bruto (PDB) yang digunakan untuk mengukur berapa besarnya pendapatan pajak di suatu negara dan dianggap dapat memberi gambaran umum atas kondisi atas perpajakan di suatu negara. Untuk meningkatkan tax ratio maka pemerintah melakukan reformasi dalam bidang perpajakan. 
Salah satu bentuk reformasi perpajakan adalah penggunaan sistem elektronik dalam administrasi perpajakan. Pengelolaan sistem administrasi pajak sangat penting dan konstruktif untuk memenuhi tuntutan Wajib Pajak sebagai pemangku kepentingan terhadap pajak (Rahayu, 2010). Terdapat 3 sistem dalam pemungutan pajak antara lain official assessment system, self assessment system, dan with holding system. Self assessment system adalah sistem pemungutan pajak yang diterapkan di Indonesia saat ini. Self assessment system yaitu sistem pemungutan pajak dengan memberi wewenang ke Wajib Pajak untuk menentukan pajak yang terutang (Mardiasmo, 2011), sehingga dalam self assessment system diperlukan kepahaman dan kepatuhan Wajib Pajak dalam kemajuan perpajakan di Indonesia sehingga pendapatan negara meningkat.

Sikap patuh pajak menjadi aspek penting mengingat Indonesia menerapkan sistem self assessment. Dengan self assessment system tentunya peran aktif dari masyarakat dalam memenuhi kewajiban perpajakannya. Sikap patuh pajak dinilai dari kesetiaannya dalam memenuhi kewajiban perpajakannya dari sisi formal dan juga materiil. Kepatuhan formal merupakan kondisi saat Wajib Pajak sanggup melakukan kewajiban perpajakannya serasi dengan tuntutan formal UU perpajakan di Indonesia, sedangkan sikap patuh secara materiil yakni serasi dengan isi dan makna UU perpajakan seperti membayar pajak tepat waktu. Upaya pemerintah untuk mencapai target pendapatan pajak yang selalu meningkat dilakukan melalui programprogram serta kebijakan sehingga dapat memenuhi target pendapatan pajak.

Pada kenyataannya, sikap patuh pajak bukan menjadi perbuatan yang mudah untuk dapat diwujudkan oleh Wajib Pajak. Kebanyakan dari masyarakat cenderung untuk dapat meloloskan diri dari kewajiban perpajakannya. Kepatuhan Wajib Pajak dalam praktiknya di Indonesia tergolong masih rendah. Menurut Aviliani, pajak PPh 21 maupun pajak badan partisipasinya masih terlalu rendah terhadap APBN. Artinya warga Indonesia kelas sedang dan atas bertambah, tapi sikap taat dalam membayar pajaknya masih kecil (cnbc.com diakses pada 26 Juni 2019). Hal tersebut juga didukung dari data realisasi tingkat kepatuhan Wajib Pajak dari tahun 2016-2018 yang mengalami penurunan. Contohnya sikap patuh Wajib Pajak dalam hal waktu, seorang Wajib Pajak bisa kerap membayar pajak secara lengkap, tetapi apabila membayar pajak terlambat maka hal tersebut tidak dianggap patuh. Kepatuhan tersebut dapat digolongkan dari sikap patuh Wajib Pajak dalam mendaftarkan diri, melaporkan pajak, dan pembayaran pajak.

Tabel 1. Realisasi Tingkat Kepatuhan Wajib Pajak

\begin{tabular}{|c|c|}
\hline Tahun & $\begin{array}{c}\text { Realisasi Tingkat Kepatuhan } \\
\text { Wajib Pajak }\end{array}$ \\
\hline
\end{tabular}

\begin{tabular}{|c|c|}
\hline 2016 & $63,15 \%$ \\
\hline 2017 & $62,96 \%$ \\
\hline 2018 & $59,89 \%$ \\
\hline
\end{tabular}

Sumber: Laporan Kinerja DJP 2016-2018

Beberapa penelitian terdahulu mengkaji faktorfaktor yang mempengaruhi tingkat kepatuhan Wajib Pajak. Salah satunya penelitian yang dilakukan Sulistyorini et al. (2017) menemukan bahwa $e$ registration mempengaruhi secara positif dan relevan terhadap tingkat kepatuhan Wajib Pajak. Akan tetapi, penelitian yang dilakukan oleh Damayanti \& Amah (2018) menemukan hasil berbeda yaitu e-registration tidak mempengaruhi kepatuhan Wajib Pajak.

Penelitian mengenai pengaruh e-filing dalam mempengaruhi kepatuhan Wajib Pajak dilakukan oleh Sulistyorini et al. (2017) dan Lado \& Budiantara (2018), menemukan kepatuhan Wajib Pajak dipengaruhi secara positif dan relevan oleh $e$ filing. Hasil berbeda ditemukan Damayanti \& Amah (2018) dan Solekhah \& Supriono (2018), dimana $e$ filing tidak mempengaruhi kepatuhan Wajib Pajak seseorang. Kemudian, Damayanti \& Amah (2018) menemukan bahwa e-billing tidak mempengaruhi kepatuhan Wajib Pajak. Sedangkan, Sulistyorini et al. (2017) menemukan bahwa e-billing mempengaruhi secara positif dan relevan kepatuhan Wajib Pajak.

Penelitian yang dilakukan Muarifah (2013) dan Kusuma (2017) telah menemukan bahwa kualitas pelayanan mempengaruhi secara positif dan relevan terhadap kepatuhan Wajib Pajak. Berbeda dengan yang ditemukan oleh Bahri et al. (2018) dimana kualitas pelayanan tidak terbukti mempengaruhi kepatuhan Wajib Pajak. Muarifah (2013), Alasfour et al. (2016), Kusuma (2017), dan Bahri et al. (2018) meneliti tentang pengaruh dari pemahaman peraturan pajak terhadap kepatuhan Wajib Pajak yang menunjukkan pengaruh positif dan relevan. Sedangkan, Solekhah \& Supriono (2018) menemukan jika pemahaman peraturan pajak tidak mempengaruhi kepatuhan Wajib Pajak.

Tujuan observasi ini untuk membuktikan secara empiris variabel $e$-registration, $e$-filing, $e$ billing, kualitas pelayanan, pemahaman peraturan pajak, dan sanksi pajak berpengaruh terhadap tingkat kepatuhan Wajib Pajak. Orisinalitas riset ini yaitu penggunaan teori Technology Acceptance Model (TAM) untuk membuktikan pengaruh variabel $e$ registration, e-filing, dan e-billing, serta metode analisis dalam riset ini adalah Structural Equation Modeling (SEM) berbasis Partial Least Square (PLS) Path Modeling.

Teori yang digunakan adalah theory of planned behaviour (TPB) dan technology acceptance model (TAM). Theory of planned behaviour (TPB) yang menguraikan keterkaitan antara tingkah laku, norma subjektif, serta persepsi kontrol perilaku dengan intention dan behaviour. Tingkah laku adalah faktor yang mucul dalam diri individu yang diamati untuk 
memberi respon positif atau negatif atas penliaian terhadap sesuatu bermanfaat bagi dirinya. Norma subjektif yakni pemikiran individu atas pendapat orang lain yang memotivasi atau tidak terhadap dirinya dalam berperilaku. Kontrol perilaku merupakan pemikiran individu tentang mudah atau sulit saat melaksanakan suatu perilaku. Tujuan teori ini untuk memahami pengaruh motivasi pada perilaku, termasuk pribadi individu dan pribadi orang lain. Dalam hal ini adalah kemauan individu untuk bertindak tunduk atau taat dalam melakukan kewajiban perpajakannya seperti dengan aparat pajak memberikan layanan terbaik, Wajib Pajak memahami peraturan, sanksi, dan prosedur perpajakan.

Teori yang memiliki model untuk memperkirakan dan menjelaskan tentang pengguna teknologi dalam menerima juga memanfaatkan teknologi untuk pekerjaannya disebut dengan teori technology acceptance model (TAM). Teori ini dikembangkan oleh Davis pada tahun 1989. Model ini memiliki dua aspek, yaitu kemanfaatan dan kemudahan penggunaan. Kemanfaatan artinya tingkat kepercayaan pengguna pada penggunaan sistem yang akan menambah kinerja user, sedangkan kemudahan pemakaian adalah tingkat keyakinan user terhadap teknologi yang bisa dipahami dan dipelajari sendiri dengan mudah. Kedua aspek tersebut mampu menggambarkan perspektif perilaku user yang menjelaskan mengenai pemikiran user akan memberikan responnya atas penggunaan teknologi. Teori ini digunakan untuk menjelaskan pengaruh dari $e$-registration, $e$-filing, dan $e$-billing .

E-Registration adalah sistem teknologi yang terhubung dengan internet dan dimanfaatkan oleh Wajib Pajak untuk memperoleh Nomor Pokok Wajib Pajak (NPWP), melakukan pengukuhan pengusaha kena pajak (PKP), dan melakukan pengubahan data diri Wajib Pajak (Nurbaiti et al., 2016). E-Registration berkaitan dengan teori technology acceptance model (TAM) dimana $e$ registration memiliki kegunaan bagi Wajib Pajak untuk mendaftarkan diri Wajib Pajak, pemindahan Wajib Pajak, penghapusan NPWP, dan pencabutan pengukuhan pengusaha kena pajak dimanapun dan kapanpun secara online. Penelitian yang dilakukan Sulistyorini et al. (2017) menemukan bahwa $e$ registration mempengaruhi secara positif terhadap kepatuhan Wajib Pajak.

\section{$\mathrm{H}_{1}$ : E-Registration berpengaruh positif terhadap} tingkat kepatuhan Wajib Pajak.

E-Filing yaitu formulir SPT masa atau tahunan dalam bentuk elektronik yang terdapat di dalam media komputer dengan penyampaiannya dilakukan secara elektronik dalam bentuk digital yang dilaporkan ke Direktorat Jenderal Pajak (DJP) dengan proses secara online dan realtime (Nugroho et al., 2014). E-Filing berkaitan dengan teori technology acceptance model (TAM) dimana $e$ filing memberikan kemudahan pada Wajib Pajak untuk melakukan pelaporan SPT secara elektronik dan online. Penelitian Sulistyorini et al. (2017) dan Lado \& Budiantara (2018) menemukan bahwa $e$ filing mempengaruhi secara positif terhadap kepatuhan Wajib Pajak.

$\mathrm{H}_{2}$ : E-Filing berpengaruh positif terhadap tingkat kepatuhan Wajib Pajak.

E-Billing merupakan teknologi yang menerbitkan angka billing untuk membayar atau menyetor pendapatan negara secara elektronik, tanpa harus menyertakan surat setoran pajak (SSP) secara manual (Sulistyorini et al., 2017). E-Billing berkaitan dengan teori technology acceptance model (TAM) dimana $e$-billing memberikan kemudahan bagi Wajib Pajak untuk melakukan pembayaran atau penyetoran pajak secara elektronik. Penelitian Sulistyorini et al. (2017) menemukan bahwa $e$ billing mempengaruhi secara positif terhadap kepatuhan Wajib Pajak.

H3: E-Billing berpengaruh positif terhadap kepatuhan Wajib Pajak.

Kualitas pelayanan pajak adalah salah satu faktor yang dapat menambah sikap patuh Wajib Pajak dalam melakukan kewajiban perpajakannya dan aparat pajak dininta wajib mempunyai pemahaman pajak yang baik terkait segala hal berkaitan dengan pajak di negara Indonesia (Pranata \& Setiawan, 2015). Kualitas pelayanan terkait dengan Subjective norm dalam theory of planned behavior (TPB) yaitu persepsi seseorang tentang pemikiran orang lain yang kontributif atau tidaknya dalam melaksanakan tindakan. Penelitian Muarifah (2013) dan Kusuma (2017) berpendapat bahwa kualitas pelayanan mempengaruhi secara positif terhadap tingkat kepatuhan Wajib Pajak.

$\mathrm{H}_{4}$ : Kualitas pelayanan berpengaruh positif terhadap kepatuhan Wajib Pajak.

Kompetensi dan mengerti peraturan perpajakan yaitu reaksi dimana Wajib Pajak mengerti tentang perpajakan dan menerapkan pemahaman itu untuk melaksanakan tanggung jawab perpajakannya. Pemahaman peraturan perpajakan berkaitan dengan theory of planned behavior (TPB) dimana tindakan individu dampak dari perceived behavioral control yaitu persepsi kemudahan atau kesulitan dalam melakukan tindakan. Perceived behavioral control menjelaskan bahwa pengendalian individu disebabkan oleh faktor internal dan eksternal dimana factor internal mencakup informasi. Penelitian Muarifah (2013), Alasfour et al. (2016), Kusuma (2017), dan Bahri et al. (2018) berpendapat bahwa pemahaman peraturan pajak mempengaruhi secara positif terhadap kepatuhan Wajib Pajak.

H5: Pemahaman peraturan pajak berpengaruh positif terhadap kepatuhan Wajib Pajak.

Sanksi pajak merupakan garansi bahwa prosedur peraturan perundang-undangan perpajakan akan dipatuhi/dituruti/ditaati atau dengan kata lain sanksi perpajakan adalah alat pelindung (preventif) supaya Wajib Pajak tidak menyalahi norma 
perpajakan (Mardiasmo, 2011). Sanksi pajak berkaitan dengan theory of planned behavior (TPB) dimana kecenderungan tindakan seseorang adalah dampak dari attitude yaitu aspek dalam diri individu untuk memberi reaksi positif maupun negatif terhadap hal yang bermanfaat bagi dirinya. Penelitian Marandu et al. (2015), Kusuma (2017), dan Solekhah \& Supriono (2018) menemukan bahwa sanksi pajak memiliki pengaruh positif terhadap tingkat kepatuhan Wajib Pajak.

\section{H6: Sanksi pajak berpengaruh positif terhadap kepatuhan Wajib Pajak.}

Berdasarkan uraian diatas, kerangka berpikir dari riset ini diilustrasikan dalam benruk Gambar 1 berikut.

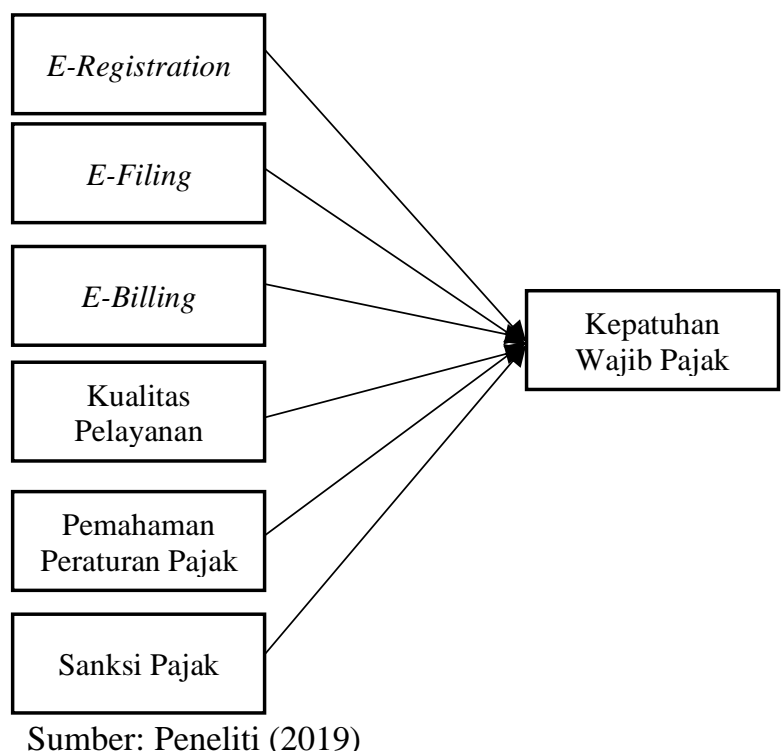

Gambar 1. Kerangka Berpikir

\section{METODOLOGI PENELITIAN}

Riset ini adalah kuantitatif dengan memanfaatkan data primer. Objek riset adalah Wajib Pajak Orang Pribadi yang tercantum di Kantor Pelayanan Pajak (KPP) Pratama Semarang Selatan. Objek penelitian dipilih karena rasio patuh Wajib Pajak di KPP Pratama Semarang Selatan cenderung fluktuatif sehingga memiliki resiko ketidakpatuhan Wajib Pajak.

Populasi di riset ini berjumlah 16.356 Wajib Pajak Orang Pribadi. Sampel pada riset ini diambil dengan teknik incidental sampling, dimana sampel didapat dari siapapun yang secara tak sengaja berjumpa dengan peneliti bisa dijadikan sebagai sampel apabila orang yang secara kebetulan berjumpa tersebut sesuai kriteria sebagai responden data. Jumlah kuesioner yang disebar yaitu sebanyak 50 kuesioner dan seluruh kuesioner kembali dengan isian jawaban dari responden secara lengkap.

\section{HASIL DAN PEMBAHASAN}

Kajian data dalam penelitian ini menggunakan metode SEM berbasis PLS path modelling memanfaatkan software smartPLS 3.0, terdiri dari dua tahap, yaitu analisis inner model dan outer model. Variabel yang dianalisis dalam SEM berbasis PLS path modeling merupakan variabel laten. PLS merupakan metode kajian SEM berbasis varian yang secara simultan bisa melaksanakan pengujian pengukuran sekalian uji skema struktural. PLS dapat sekali lalu mengukur konstruk yang dibuat dengan indikator reflektif maupun formatif.

Statistik deskriptif memberi ilustrasi data yang diamati dari mean, standar deviasi, varian, nilai maksimum, dan nilai minimum. Hasil pengujian statistik deskriptif menggunakan smartPLS 3.0 yang dapat diamati pada Tabel 4. berikut.

Tabel 2. Analisis Statistik Deskriptif

\begin{tabular}{|c|c|c|c|c|}
\hline \multirow[b]{2}{*}{ Indikator } & \multicolumn{4}{|c|}{ Statistik Deskriptif } \\
\hline & Mean & Min & $\operatorname{Max}$ & $\begin{array}{c}\text { Standar } \\
\text { Deviation }\end{array}$ \\
\hline & $\mathrm{n}=50$ & & & \\
\hline \multicolumn{5}{|c|}{ Variabel Kepatuhan Wajib Pajak } \\
\hline Mendaftarkan diri & 6,660 & 5 & 8 & 0,982 \\
\hline $\begin{array}{ll}\text { Melaporkan } & \text { SPT } \\
\text { tepat waktu } & \end{array}$ & 9,740 & 6 & 12 & 1,454 \\
\hline $\begin{array}{l}\text { Membayar pajak } \\
\text { dengan benar }\end{array}$ & 9,180 & 7 & 12 & 1,366 \\
\hline \multicolumn{5}{|c|}{ Variabel E-Registration } \\
\hline User friendly & 8,900 & 6 & 12 & 1,515 \\
\hline Efektifitas & 6,420 & 4 & 8 & 0,928 \\
\hline Kebermanfaatan & 8,640 & 5 & 12 & 1,782 \\
\hline \multicolumn{5}{|l|}{ Variabel E-Filing } \\
\hline User friendly & 9,380 & 6 & 12 & 1,563 \\
\hline Efektifitas & 6,580 & 4 & 8 & 0,928 \\
\hline Kebermanfaatan & 9,160 & 6 & 12 & 1,707 \\
\hline \multicolumn{5}{|l|}{ Variabel E-Billing } \\
\hline User friendly & 9,160 & 6 & 12 & 1,633 \\
\hline Efektifitas & 6,440 & 5 & 8 & 1,033 \\
\hline Kebermanfaatan & 9,080 & 5 & 12 & 1,712 \\
\hline \multicolumn{5}{|l|}{ Kualitas Pelayanan } \\
\hline Keandalan & 9,600 & 6 & 12 & 1,552 \\
\hline Ketanggapan & 9,560 & 6 & 12 & 1,500 \\
\hline Jaminan & 6,800 & 4 & 8 & 1,030 \\
\hline \multicolumn{5}{|c|}{ Pemahaman Peraturan Pajak } \\
\hline $\begin{array}{l}\text { Pengetahuan } \\
\text { ketentuan pajak }\end{array}$ & 9,320 & 6 & 12 & 1,558 \\
\hline $\begin{array}{l}\text { Pengetahuan } \\
\text { sistem pajak }\end{array}$ & 6,380 & 5 & 8 & 0,878 \\
\hline $\begin{array}{l}\text { Pengetahuan } \\
\text { fungsi pajak }\end{array}$ & 9,920 & 8 & 12 & 1,322 \\
\hline \multicolumn{5}{|l|}{ Sanksi Pajak } \\
\hline $\begin{array}{l}\text { Sanksi pajak } \\
\text { cukup berat }\end{array}$ & 8,780 & 5 & 12 & 1,607 \\
\hline $\begin{array}{l}\text { Sanksi pajak } \\
\text { untuk mendidik }\end{array}$ & 9,060 & 6 & 12 & 1,268 \\
\hline $\begin{array}{l}\text { Sanksi pajak } \\
\text { tanpa toleransi }\end{array}$ & 6,120 & 4 & 8 & 0,872 \\
\hline
\end{tabular}


Variabel kepatuhan Wajib Pajak, $e$ registration, e-filing, e-billing, kualitas pelayanan, pemahaman peraturan pajak, dan sanksi pajak memiliki angka standar deviasi lebih kecil dibandingkan angka rata-rata. Hasil tersebut menandakan kalau simpangan datanya relatif kecil. Simpangan data yang kecil menunjukkan bahwa data kepatuhan Wajib Pajak, e-registration, e-filing, e-billing, kualitas pelayanan, pemahaman peraturan pajak, dan sanksi pajak dapat dikatakan cukup baik.

Hasil output smartPLS menunjukkan bahwa variabel kepatuhan Wajib Pajak, e-registration, $e$ filing, e-billing, kualitas pelayanan, pemahaman peraturan pajak, dan sanksi pajak memiliki nilai rho_A diatas 0,7. Hal ini mengindikasikan bahwa masing-masing variabel dinyatakan reliabel. Nilai outer VIF pada penelitian ini menunjukkan bahwa masing-masing indikator mempunyai angka VIF kurang dari 10. Keadaan ini mengindikasikan bahwa indikator-indikator yang digunakan tidak terdapat multikol.

Kepatuhan Wajib Pajak mempunyai angka adjusted $\mathrm{R}^{2}$ sebesar 0,587 yang berarti bahwa pengaruh variabel $e$-registration, $e$-filing, e-billing, kualitas pelayanan, pemahaman peraturan pajak, dan sanksi pajak dalam menjelaskan kepatuhan Wajib Pajak adalah 58,7\% dan sisanya 41,3\% berdampak dari variabel lainnya di luar model penelitian. Nilai $\mathrm{R}^{2}$ yang dihasilkan setinggi 0,638 sehingga termasuk dalam kategori kuat karena mendekati 0,67.

Pengujian hipotesis pada SEM PLS yaitu uji relevansi dan arah pengaruh. Uji relevansi dilakukan dengan membandingkan hasil $p$-value dengan nilai $\alpha$ yang dipergunakan yaitu sebesar 0,05. Arah pengaruh ditunjukkan dengan hasil koefisien jalur apakah positif atau negatif. Hasil pengujian terhadap hipotesis dalam penelitian ini, dapat disimpulkan bahwa diperoleh 3 hipotesis yang diterima dan 3 hipotesis yang ditolak. Rangkuman hasil pengujian dirangkum sebagai berikut.

Tabel 3. Hasil Pengujian Hipotesis

\begin{tabular}{|c|l|c|c|}
\hline Hipotesis & \multicolumn{1}{|c|}{ Pernyataan } & $\begin{array}{c}\text { Original } \\
\text { Sample }\end{array}$ & p-value \\
\hline $\mathrm{H} 1$ & $\begin{array}{l}\text { E-Registration } \\
\text { berpengaruh positif } \\
\text { terhadap tingkat } \\
\text { kepatuhan Wajib } \\
\text { Pajak }\end{array}$ & 0,273 & 0,016 \\
\hline $\mathrm{H} 2$ & $\begin{array}{l}\text { E-Filing } \\
\text { berpengaruh positif } \\
\text { terhadap tingkat } \\
\text { kepatuhan Wajib } \\
\text { Pajak }\end{array}$ & 0,421 & 0,008 \\
\hline $\mathrm{H} 3$ & $\begin{array}{l}\text { E-Billing } \\
\text { berpengaruh positif } \\
\text { terhadap tingkat } \\
\text { kepatuhan Wajib } \\
\text { Pajak }\end{array}$ & $-0,050$ & 0,757 \\
\hline $\mathrm{H} 4$ & $\begin{array}{l}\text { Kualitas pelayanan } \\
\text { berpengaruh positif }\end{array}$ & 0,347 & 0,045 \\
\hline
\end{tabular}

\begin{tabular}{|c|c|c|c|}
\hline & $\begin{array}{lr}\text { terhadap } & \text { tingkat } \\
\text { kepatuhan } & \text { Wajib } \\
\text { Pajak } & \\
\end{array}$ & & \\
\hline H5 & $\begin{array}{lr}\text { Pemahaman } & \\
\text { peraturan } & \text { pajak } \\
\text { berpengaruh } & \text { positif } \\
\text { terhadap } & \text { tingkat } \\
\text { kepatuhan } & \text { Wajib } \\
\text { Pajak } & \end{array}$ & 0,134 & 0,448 \\
\hline H6 & $\begin{array}{lr}\text { Sanksi } & \text { pajak } \\
\text { berpengaruh } & \text { positif } \\
\text { terhadap } & \text { tingkat } \\
\text { kepatuhan } & \text { Wajib } \\
\text { Pajak } & \\
\end{array}$ & $-0,051$ & 0,724 \\
\hline
\end{tabular}

Sumber: Output smartPLS, 2019

\section{Pengaruh E-Registration terhadap Kepatuhan Wajib Pajak}

Hasil pengujian hipotesis menunjukkan bahwa e-registration memiliki nilai koefisien positif sebesar 0,273 dan tingkat relevansi 0,016<0,050. Berdasarkan nilai tersebut e-registration berpengaruh positif dan relevan terhadap kepatuhan Wajib Pajak. Sejalan dengan teori technology acceptance model (TAM), bahwa e-registration memiliki aspek kemanfaatan dan kemudahan penggunaan. E-Registration memberikan kemudahan bagi Wajib Pajak untuk melakukan pendaftaran Wajib Pajak, pemindahan Wajib Pajak, penghapusan NPWP, dan pencabutan pengukuhan pengusaha kena pajak melalui internet sehingga bias dilakukan dimanapun dan kapanpun. E-Registration sangat mudah untuk dipelajari oleh Wajib Pajak sehingga menjadi cara yang praktis dalam mendaftarkan diri sebagai Wajib Pajak.

Penggunaan e-registration akan berdampak pada kepatuhan Wajib Pajak sehingga semakin banyak Wajib Pajak yang menggunakan $e$ registration sehingga makin tinggi sikap patuh Wajib Pajak. Hasil penelitian ini sependapat dengan penelitian yang dilaksanakan Sulistyorini et al. (2017) menyatakan bahwa ada pengaruh positif dan relevan e-registration terhadap kepatuhan Wajib Pajak.

\section{Pengaruh E-Filing terhadap Kepatuhan Wajib Pajak}

Hasil pengujian hipotesis menunjukkan bahwa $e$-filing mempunyai angka koefisien positif senilai 0,421 dan tingkat relevansi $0,008<0,050$. Berdasarkan nilai tersebut $e$-filing berdampak positif dan relevan terhadap sikap patuh Wajib Pajak. Sejalan dengan technology acceptance model (TAM), kalau e-filing mempunyai aspek kemanfaatan dan kemudahan penggunaan. E-Filing memberi kemudahan bagi Wajib Pajak untuk melaksanakan penyampaian SPT atau perpanjangan SPT tahunan secara elektronik yang dilakukan secara online. E-Filing memiliki tingkat kepercayaan yang tinggi dari Wajib Pajak sehingga menjadi opsi dalam pelaporan SPT tanpa perlu 
datang ke kantor pajak dan melalui media elektronik.

E-Filing sangat mudah untuk dipelajari Wajib Pajak sehingga penggunaan $e$-filing menjadi cara termudah dalam pelaporan SPT. Penelitian yang dilakukan Sulistyorini et al. (2017) dan Lado \& Budiantara (2018) menyatakan hasil yang serupa bahwa $e$-filing berdampak secara positif dan relevan terhadap sikap patuh Wajib Pajak.

\section{Pengaruh E-Billing terhadap Kepatuhan Wajib Pajak}

Hasil uji hipotesis menetapkan bahwa $e$-billing berdampak negatif namun tidak relevan dengan angka koefisien senilai $-0,050$ dan tingkat relevan $0,757>0,050$. Temuan ini tidak sesuai dengan teori technology acceptance model (TAM) yang menyatakan dalam teknologi terdapat dua aspek yaitu kemanfaatan dan kemudahan penggunaan. EBilling digunakan sebagai alat pembayaran pajak saat ini namun kurangnya sosialisai terhadap cara menggunakan e-billing menyebabkan Wajib Pajak masih menggunakan cara manual yaitu dengan cara pembayaran tunai. Hasil penelitian ini tidak sejalan dengan penelitian Sulistyorini et al. (2017) yang membuktikan bahwa e-billing berpengaruh positif dan relevan terhadap sikap patuh Wajib Pajak. Damayanti \& Amah (2018) menunjukkan hasil yang sama dengan penelitian ini yaitu e-billing tidak berpengaruh terhadap kepatuhan Wajib Pajak.

\section{Pengaruh Kualitas Pelayanan terhadap Kepatuhan Wajib Pajak}

Hasil pengujian hipotesis menunjukkan bahwa kualitas pelayanan memiliki nilai koefisien sebesar 0,347 dan tingkat relevansi $0,045<0,050$. Berdasarkan nilai tersebut kualitas pelayanan berdampak positif dan relevan terhadap sikap patuh Wajib Pajak. Sesuai dengan theory of planned behavior yaitu subjective norm yang artinya persepsi orang lain yang memotivasi atau tidaknya dalam melaksanakan tindakan. Hasil penelitian menunjukkan semakin baik layanan yang dibantu oleh aparat pajak akan semakin tinggi tingkat patuh Wajib Pajak, sebaliknya jika pelayanan yang diberikan oleh petugas pajak buruk akan semakin rendah tingkat patuh Wajib Pajak.

Riset yang dilakukan Bahri et al. (2018) tidak sejalan dengan penelitian ini yang berpendapat bahwa kualitas pelayanan tidak berdampak terhadap sikap patuh Wajib Pajak. Penelitian Muarifah (2013) dan Kusuma (2017) menunjukkan hasil yang serupa bahwa kualitas pelayanan berpengaruh positif dan relevan terhadap sikap patuh Wajib Pajak.

Pengaruh Pemahaman Peraturan
Pajak
Herhadap Kepatuhan Wajib Pajak
Hasil uji hipotesis menunjukkan bahwa
pemahaman peraturan pajak memiliki nilai koefisien
0,134 dan tingkat relevansi $0,448>0,050$.

Berdasarkan hasil tersebut pemahaman peraturan perpajakan berpengaruh positif dan tidak relevan. Hasil riset tidak sejalan dengan theory of planned behavior yang menyatakan niat didasari oleh perceived behavioral control yaitu persepsi mudah atau sulit dalam melangsungkan suatu tindakan. Wajib Pajak saat ini memiliki pemahaman peraturan pajak yang luas, sehingga kecenderungan perilaku Wajib Pajak untuk bersikap patuh pajak dianggap sebagai kewajiban.

Riset ini tidak sependapat dengan penelitian Muarifah (2013), Alasfour et al. (2016), Kusuma (2017), dan Bahri et al. (2018) yang berpendapat bahwa pemahaman peraturan perpajakan berdampak positif dan relevan terhadap sikap patuh Wajib Pajak. Penelitian Solekhah \& Supriono (2018) menunjukkan hasil yang serupa dengan penelitian ini yaitu pemahaman peraturan perpajakan tidak berdampak terhadap sikap patuh Wajib Pajak.

\section{Pengaruh Sanksi Pajak terhadap Kepatuhan Wajib Pajak}

Hasil pengujian hipotesis menggambarkan sanksi pajak memiliki angka koefisien senilai -0,051 dengan tingkat relevansi 0,724>0,050. Hasil tersebut menunjukkan bahwa sanksi pajak berdampak negatif dan tidak relevan. Hasil riset ini tidak sejalan dengan theory of planned behavior bahwa niat didasari sikap yang artinya aspek dalam diri individu yang diamati untuk memberikan reaksi negatif atau positif pada nilai terhadap hal bermanfaat bagi dirinya. Sanksi pajak yang berlaku saat ini sudah tegas sehingga kecenderungan perilaku Wajib Pajak untuk menghindari pajak dianggap sebagai hal yang tidak beretika.

Hasil penelitian Marandu et al. (2015), Kusuma (2017), dan Solekhah \& Supriono (2018) tidak sejalan dengan riset ini yang menyatakan kalau sanksi pajak berdampak positif dan relevan terhadap kepatuhan Wajib Pajak. Penelitian Bahri et al. (2018) menunjukkan hasil yang serupa dengan penelitian ini menunjukkan kalau sanksi pajak tidak berdampak terhadap sikap patuh Wajib Pajak.

\section{KESIMPULAN}

Pengujian hipotesis menemukan hasil yang membuktikan bahwa dengan e-registration, e-filing, dan kualitas pelayanan yang baik akan membuat tingkat kepatuhan Wajib Pajak semakin tinggi. Temuan tersebut menunjukkan bahwa $e$-registration dan e-filing mempermudah Wajib Pajak Orang Pribadi melangsungkan tanggung jawab perpajakannya. Kualitas pelayanan yang semakin baik akan memotivasi Wajib Pajak Orang Pribadi untuk bersikap taat dan tunduk pajak sehingga kualitas pelayanan berpengaruh positif. Kemudian $e$ billing, pemahaman peraturan perpajakan, dan sanksi pajak tidak mempengaruhi sikap patuh Wajib Pajak Orang Pribadi.

Saran untuk pemerintah diharapkan untuk 
mempertahankan kualitas pelayanansehingga timbul rasa sukarela untuk melakukan perpajakannya. Penelitian ini memiliki keterbatasan yaitu tidak dilakukannya wawancara dalam proses penelitian karena kesibukan responden dan waktu yang terbatas. Penelitian selanjutnya diharapkan dapat menggunakan metode wawancara agar dapat membantu dalam mengendalikan jawaban dari tiap responden.

\section{REFERENSI}

Alasfour, F., Samy, M., \& Bampton, R. (2016). The Determinants of Tax Morale and Tax Compliance: Evidence from Jordan. In Advances in Taxation (Vol. 23). https://doi.org/10.1108/S1058749720160000023005

Bahri, S., Diantimala, Y., \& Majid, M. S. A. (2018). Pengaruh Kualitas Pelayanan Pajak, Pemahaman Peraturan Perpajakan serta Sanksi Perpajakan terhadap Kepatuhan Wajib Pajak. 4(September), 318-334.

CNBC. (2019). Kepatuhan Pajak di Indonesia Masih Rendah. Retrieved June 26, 2019, from cnbc website:

https://www.cnbcindonesia.com/news/201903 26160157-4-63008/aviliani-kepatuhan-pajakdi-indonesia-masih-rendah

Damayanti, L. dwi, \& Amah, N. (2018). Kepatuhan Wajib Pajak Orang Pribadi: Pengaruh Modernisasi Sistem Administrasi dan Pengampunan Pajak. Jurnal Akuntansi Dan Pendidikan, 7(1), 57-71.

Kusuma, K. C. (2017). Pengaruh Kualitas Pelayanan Pajak, Pemahaman Peraturan Perpajakan serta Sanksi Perpajakan terhadap Kepatuhan WPOP. 1-14.

Lado, Y. O., \& Budiantara, M. (2018). Pengaruh Penerapan Sistem E-Filing Terhadap Kepatuhan Wajib Pajak Orang Pribadi Pegawai Negeri Sipil Dengan Pemahaman Internet Sebagai Variabel Pemoderasi (Studi Kasus pada Dinas Perindustrian dan Perdagangan DIY). Jurnal Riset Akuntansi Mercu Buana, 4(1), 59. https://doi.org/10.26486/jramb.v4i1.498

Marandu, E. E., Mbekomize, C. J., \& Ifezue, A. N.
(2015). Determinants of Tax Compliance: A Review of Factors and Conceptualizations. International Journal of Economics and Finance, 7(9).

Mardiasmo. (2011). Perpajakan. Yogyakarta: Penerbit Andi.

Muarifah, T. (2013). Pengaruh Pemahaman Pajak, Kualitas Pelayanan Aparat Pajak dan Sikap Wajib Pajak terhadap Kepatuhan Wajib Pajak.

Nugroho, D. A. D., Handayani, S. R., \& Saifi, M. (2014). Pengaruh Layanan Drop Box Dan EFiling Terhadap Tingkat Kepatuhan Penyampaian Surat Pemberitahuan ( Spt ) Tahunan Pajak Penghasilan. E- Perpajakan, 1(1), 1-10.

Nurbaiti, E., Susilo, H., \& Agusti, R. R. (2016). Pengaruh Implementasi Sistem Elektronik Bagi Wajib Pajak Terhadap Kualitas Pelayanan Administrasi Perpajakan. Jurnal Perpajakan (JEJAK), 9(1), 1-9.

Pranata, P. A., \& Setiawan, P. E. (2015). Pendapatan Pajak Daerah Dengan Meningkatkan Sanksi Perpajakan, Kualitas Pelayanan dan Kewajiban Moral pada Kepatuhan Wajib Pajak. E-Jurnal Akuntansi Universitas Udayana, 2, 456-473.

Rahayu, S. K. (2010). Perpajakan Indonesia: Konsep dan Aspek Formal. Yogyakarta: Graha Ilmu.

Solekhah, P., \& Supriono. (2018). Pengaruh Penerapan Sistem E-Filing, Pemahaman Perpajakan, Kesadaran Wajib Pajak dan Sanksi Perpajakan Terhadap Kepatuhan Wajib Pajak Orang Pribadi di KPP Pratama Purworejo. Journal of Economic, Management, Accounting and Technology, l(1), 74-90. https://doi.org/10.32500/jematech.v1i1.214

Sulistyorini, M., Nurlaela, S., \& S. Chomsatu, Y. (2017). Pengaruh Penggunaan Sistem Administrasi E-Registration, E- Billing, E-Spt, Dan E-Filling Terhadap Kepatuhan Wajib Pajak (Studi Pada Wajib Pajak Orang Pribadi Di Rsud Dr. Moewardi Surakarta). Perpajakan, 371-379. 